\title{
First detection of F1534C knockdown resistance mutation in Aedes aegypti (Diptera: Culicidae) from Cameroon
}

\author{
Aurelie P. Yougang ${ }^{1,2 \dagger}$, Basile Kamgang ${ }^{1 *}\left(\mathbb{D}\right.$, Theodel A. Wilson Bahun ${ }^{1,3}$, Armel N. Tedjou ${ }^{1,2}$, \\ Daniel Nguiffo-Nguete ${ }^{1,4}$, Flobert Njiokou ${ }^{2}$ and Charles S. Wondji, ${ }^{1,5}$
}

\begin{abstract}
Background: Aedes borne viral diseases, notably dengue, are increasingly reported in Cameroon with Aedes aegypti being a major vector. Data on insecticide resistance of this vector and underlying mechanisms needed for outbreak preparedness remain scarce in Cameroon. Here, we present the nationwide distribution of insecticide resistance in $A e$. aegypti and investigate the potential resistance mechanisms involved.

Methods: Immature stages of Ae. aegypti were collected between March and July 2017 in 13 locations across Cameroon and reared until G1/G2/G3 generation. Larval, adult bioassays, and piperonyl butoxide (PBO) synergist assays were carried out according to World Health Organization guidelines. F1534C mutation was genotyped using allele specific polymerase chain reaction in field collected adults (Go) and the polymorphism of the sodium channel gene was assessed. The $x^{2}$ test was used to compare the mortality rate between bioassays with insecticides only and bioassays after preexposure to PBO synergist.
\end{abstract}

Results: Larval bioassay revealed that all the three populations tested with temephos were susceptible. Adult bioassays showed a good level of susceptibility toward both pyrethroids tested, $0.25 \%$ permethrin and $0.05 \%$ deltamethrin, with six out of 10 populations susceptible. However, two populations (Douala and Edéa) were resistant (deltamethrin [73.2-92.5\% mortality], permethrin [2.6-76.3\% mortality]). The resistance to 4\% dichlorodiphenyltrichloroethane was observed in four out of 10 populations tested (16.8-87.1\% mortality). Resistance was also reported to carbamates including $0.1 \%$ propoxur ( $60.8-87.1 \%$ mortality) and to $0.1 \%$ bendiocarb ( $82.9 \%$ mortality). All populations tested were fully susceptible to $1 \%$ fenitrothion. A partial recovery of susceptibility was observed in the pyrethroid resistant population of Douala after pre-exposed to PBO suggesting the implication of cytochrome P450 monoxygenases permethrin resistance. Genotyping and sequencing detected the F1534C kdr mutation in the two pyrethroid resistant locations of Edéa and Douala, with allelic frequency of 3.3\% and 33.3\% respectively. However, the high genetic diversity of the sodium channel gene supports the recent introduction of this mutation in Cameroon.

Conclusions: This study revealed the contrasting resistance profiles to insecticides of Ae. aegypti populations in Cameroon suggesting that, instead of a unique nationwide control approach, a regionally adapted strategy will be needed to control this vector. The localised distribution of the F1534C kdr mutation supports this region-specific control strategy.

\footnotetext{
*Correspondence: kamgang_d@yahoo.fr; basile.kamgang@crid-cam.net

${ }^{\dagger}$ Aurelie P. Yougang and Basile Kamgang have contribute equally.

${ }^{1}$ Centre for Research in Infectious Diseases, P.O. Box 13591, Yaoundé, Cameroon

Full list of author information is available at the end of the article
} permits use, sharing, adaptation, distribution and reproduction in any medium or format, as long as you give appropriate credit to the original author(s) and the source, provide a link to the Creative Commons licence, and indicate if changes were made. The images or other third party material in this article are included in the article's Creative Commons licence, unless indicated otherwise in a credit line to the material. If material is not included in the article's Creative Commons licence and your intended use is not permitted by statutory regulation or exceeds the permitted use, you will need to obtain permission directly from the copyright holder. To view a copy of this licence, visit http://creativecommons.org/licenses/by/4.0/. The Creative Commons Public Domain Dedication waiver (http://creativeco mmons.org/publicdomain/zero/1.0/) applies to the data made available in this article, unless otherwise stated in a credit line to the data. 
Keywords: Aedes aegypti, Insecticide resistance, Kdr mutation, Cameroon, Arbovirus

\section{Background}

The mosquito Aedes aegypti Linneaus, 1762 (Diptera: Culicidae) is the main vector of several arboviral related diseases such as dengue, Zika, chikungunya, and yellow fever in subtropical and tropical world. This domestic mosquito usually bites during daylight, feeding mainly on humans, mating and resting indoor/ outdoor, and breeding in man-made containers in and around human habitations [1].

In Cameroon, where several cases of arboviral related diseases such as dengue [2-5], chikungunya [6, 7], yellow fever [8] and Zika [9] are increasingly reported, it was demonstrated that Ae. aegypti is present across the country and found as dominant Aedes species in some locations notably in the northern part [10]. It was also demonstrated that local Ae. aegypti populations are able to transmit dengue [11], Zika [12] and yellow fever [13] viruses in different urban settings in Cameroon. Prevention of large outbreaks caused by these virus relies on control of Aedes vectors based on destruction of breeding sites and insecticide-based interventions such as treatment of breeding sites with larvicides, insecticide-treated nets [14] and space spraying of adulticides in emergency situations $[15,16]$. However, at the operational level, many vector control programmes are facing the challenge of the development of insecticide resistance in Ae. aegypti. Indeed, Ae. aegypti has been found to be resistant to several classes of insecticides in different regions across the world with significant variation according to the population's origin and the insecticide classes [17-24].

The insecticide resistance in mosquitoes is primarily associated to two main mechanisms: insensitivity of target sites (target-site resistance) due to mutations that reduce the binding affinity between the insecticide and the target site, and metabolic resistance resulting in an overproduction of enzymes that will facilitate the detoxification of insecticides $[25,26]$. The metabolic resistance through overexpression of detoxification genes is a common resistance mechanism in Ae. aegypti as well as in Ae. albopictus. The three main enzyme families responsible for insecticide resistance in mosquitoes are the monooxygenases (cytochrome P450s), glutathione S-transferases (GSTS), and carboxylesterases $(C O E s)[26,27]$.

Target site resistance is caused by mutations in target genes such as the acetylcholinesterase (Ace-1), the $G A B A$ receptor and the voltage-gated sodium channel (VGSC) causing knockdown resistance $(k d r)$. One of the most important target site resistance for mosquitoes is $k d r$ as it confers resistance to both pyrethroids and dichlorodiphenyltrichloroethane (DDT). Eleven $k d r$ mutations in VGSC domain I-IV have been identified in Ae. aegypti around the world and the association between F1534C, V1016G, I1011M, and V410L mutations and pyrethroid resistance has been established [22, 28, 29]. In Africa 1534 and 1016 mutations have been previously reported in Ae. aegypti in Burkina-Faso and Ghana [21], and 410 mutation in Angola [30]. In Cameroon, data on insecticide resistance in Ae. aegypti and resistance mechanisms involved are very limited apart from the preliminary studies highlighting the resistance of this species to DDT, deltamethrin, and bendiocarb in some locations and suggesting the implication of cytochrome P450 enzymes in pyrethroids and DDT resistance $[19,20]$. Thereby, we present here the nationwide distribution of insecticide resistance to Ae. aegypti and investigate the potential implication of $1534 k d r$ mutation in the pyrethroid resistance. This was done by assessing the presence and distribution of the 1534C resistant allele and analysing the genetic diversity of the related portion of the sodium channel gene country-wide.

\section{Methods}

\section{Collection of mosquitoes}

Immature stages of Aedes were collected between March and July 2017 in 13 locations across Cameroon (Fig. 1): Maroua (10 $\left.35^{\prime} \mathrm{N} ; 14^{\circ} 18^{\prime} \mathrm{E}\right)$, Benoué national park $\left(08^{\circ} 20^{\prime} \mathrm{N} ; 13^{\circ} 50^{\prime} \mathrm{E}\right)$, Garoua $\left(09^{\circ} 18^{\prime} \mathrm{N} ; 13^{\circ} 24^{\prime}\right.$ E), Mbé $\left(07^{\circ} 51^{\prime} \mathrm{N} ; 13^{\circ} 35^{\prime} \mathrm{E}\right)$, Banyo $\left(06^{\circ} 45^{\prime} \mathrm{N} ; 11^{\circ}\right.$ $\left.49^{\prime} \mathrm{E}\right)$, Tibati $\left(06^{\circ} 28^{\prime} \mathrm{N}\right.$; $\left.12^{\circ} 38^{\prime} \mathrm{E}\right)$, Meiganga $\left(06^{\circ} 31^{\prime} \mathrm{N}\right.$; $\left.14^{\circ} 18^{\prime} \mathrm{E}\right)$, Ngaoundéré $\left(07^{\circ} 19^{\prime} \mathrm{N} ; 13^{\circ} 35^{\prime} \mathrm{E}\right)$, Edéa $\left(03^{\circ}\right.$ $\left.48^{\prime} \mathrm{N} ; 10^{\circ} 08^{\prime} \mathrm{E}\right)$, Limbé $\left(04^{\circ} 00^{\prime} \mathrm{N} ; 09^{\circ} 13^{\prime} \mathrm{E}\right)$, Douala $\left(04^{\circ} 03^{\prime} \mathrm{N} ; 09^{\circ} 42^{\prime} \mathrm{E}\right)$, Melong $\left(05^{\circ} 07^{\prime} \mathrm{N} ; 09^{\circ} 57^{\prime} \mathrm{E}\right)$, and Yaoundé $\left(03^{\circ} 52^{\prime} \mathrm{N} ; 11^{\circ} 31^{\prime} \mathrm{E}\right)$. Detailed characteristics of each collection site are presented in previous studies [10]. In each location, mosquitoes were collected in peri-urban and downtown at a minimum of 20 positive larval breeding places per site. Larvae/pupae of Aedes mosquitoes were transported to an insectary and pooled together according to the city and maintained until they emerged as adults before morphological identification using a suitable taxonomic key [31,32]. Adult mosquitoes were maintained at insectary and reared in the controlled conditions $\left(27^{\circ} \mathrm{C} \pm 2{ }^{\circ} \mathrm{C}\right.$; relative humidity $80 \% \pm 10 \%)$. Mosquitoes identified as $\mathrm{Ae}$. 


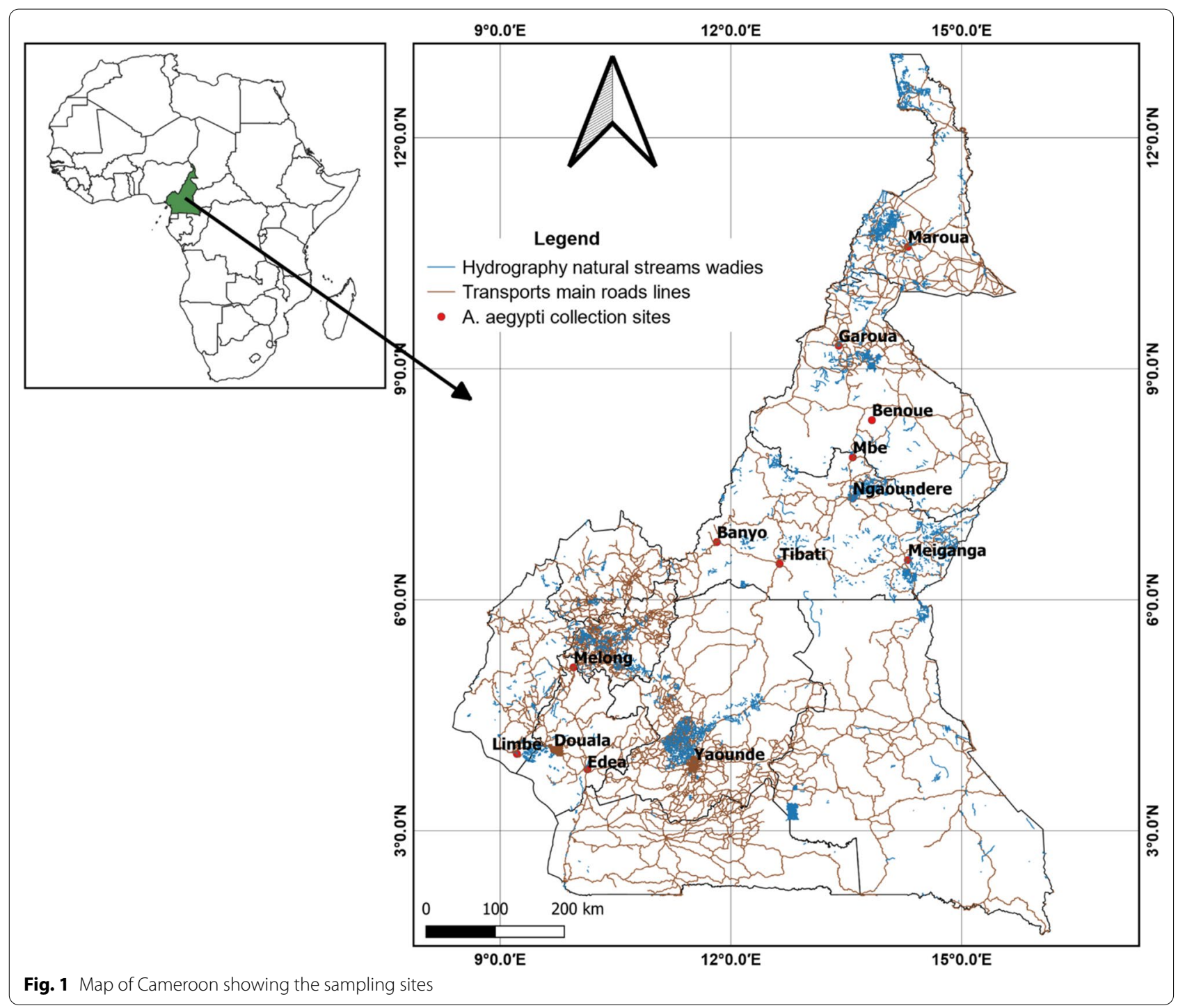

aegypti were reared until generation until G1/G2/G3. Ae. aegypti New Orleans (NO) strain was used as reference susceptible strain.

\section{Insecticides susceptibility tests \\ Larval bioassays}

Larval tests were conducted following World Health Organization (WHO) protocol [33]. The late third- and early fourth instar larvae were used for each mosquito population. Four replicates were tested with 20-25 larvae per replicate and per concentration. The susceptibility of larvae was evaluated against technical-grade temephos (97.3\%; Sigma Aldrich-Pestanal, Seelze, Germany). First, stock solutions and serial dilution were prepared in $95 \%$ ethanol for temephos and stored at $4{ }^{\circ} \mathrm{C}$. Seven concentrations ranging from 0.0005 and $0.006 \mathrm{mg} / \mathrm{L}$ have been used to test both field strain and susceptible lab strain (New Orleans). Larvae were not fed during the experiment and the conditions of the room were $27 \pm 2{ }^{\circ} \mathrm{C}$ (temperature) and $70 \pm 10 \%$ (relative humidity). Larval mortality was recorded after $24 \mathrm{~h}$ of exposure to larvicide.

All the results were analyzed with win DL software (v. 2.0, CIRAD-CD, Montpellier, France) to determine the lethal concentration for $50 \%\left(\mathrm{LC}_{50}\right)$ and $95 \%\left(\mathrm{LC}_{95}\right)$ of the populations. Resistance ratios $\left(\mathrm{RR}_{50}\right.$ and $\left.\mathrm{RR}_{95}\right)$ were calculated using $\mathrm{LC}_{50}$ and $\mathrm{LC}_{95}$ rates from Ae. aegypti field populations compared with the $\mathrm{LC}_{50}$ and $\mathrm{LC}_{95}$ rates of the reference strain. The resistance levels were ranked into three categories: low resistance $\left(R_{50}<5\right)$, medium or moderate resistance $\left(5 \leq R R_{50} \leq 10\right)$, and high resistance $\left(\mathrm{RR}_{50}>10\right)$ [33]. 


\section{Insecticides susceptibility bioassays}

Adult bioassays were carried out according to WHO guidelines [33]. Six insecticides were tested: $0.25 \%$ permethrin (Type I pyrethroid), 0.05\% deltamethrin (Type II pyrethroid), 4\% DDT (organochlorine), $0.1 \%$ propoxur (carbamate), $0.1 \%$ bendiocarb (Carbamate), and $1 \%$ fenitrothion (organophosphate). Four replicates of 20-25 unfed two to five days old female Ae. aegypti were exposed to insecticide-impregnated papers for $1 \mathrm{~h}$ under the insectary conditions described above, and then transferred to holding tubes with access to $10 \%$ sugar solution. The mortality rate was recorded $24 \mathrm{~h}$ later. The dead mosquitoes were stored in silica gel desiccant and the survivor in RNA later at $-80{ }^{\circ} \mathrm{C}$ freezer. The resistance status was defined as follows: susceptible (mortality rate between 98 and 100\%), probable resistance (mortality rate between 90 and 98\%) and resistant (mortality rate inferior to $90 \%$ ) [33].

\section{Synergist assays}

In order to investigate the potential role of oxidases in the metabolic resistance mechanism, synergist assay was performed in Douala population using $4 \%$ piperonyl butoxide (PBO). 2-5-day-old adults were pre-exposed for one hour to $\mathrm{PBO}$-impregnated papers and immediately exposed to permethrin. Mortality was scored $24 \mathrm{~h}$ later and compared to the results obtained with permethrin without synergist according to the WHO standard [34]

\section{F1534C $k d r$ genotyping using allele specific polymerase chain reaction (PCR)}

As previous study in Central Africa [18] had not reported any mutation associated to pyrethroid resistance, we decided to focus our analysis in F1534C mutation which is mostly found worldwide including in West Africa $[21,35]$. For this purpose, genomic DNA of 30 individual mosquitoes per populations was extracted using Livak protocol [36]. That DNA was used to genotype the F1534C mutation which has been described to be associated to pyrethroids and DDT resistance. Allele specific PCR assays were performed following using Harris et al. protocol [37]. Each PCR reaction was performed in a $15 \mu$ volume containing: $1 \mu \mathrm{l}$ of DNA sample, 0.4 units of Kapa Taq DNA polymerase, $0.12 \mu \mathrm{l}$ of $25 \mathrm{mmol} / \mathrm{L}$ dNTPs (0.2 mmol/L), $0.75 \mu \mathrm{l}$ of $25 \mathrm{mmol} / \mathrm{L} \mathrm{MgCl}_{2}(1.5 \mathrm{mmol} / \mathrm{L})$, $1.5 \mu \mathrm{l}$ of $10 \times$ PCR buffer $(1 \times), 0.51 \mu \mathrm{l}$ of each primers $(0.34 \mathrm{mmol} / \mathrm{L})$. The amplification consisted of $95{ }^{\circ} \mathrm{C}$ for a 5 min heat activation step, followed by 35 cycles of $94{ }^{\circ} \mathrm{C}$ for $30 \mathrm{~s}, 55{ }^{\circ} \mathrm{C}$ for $30 \mathrm{~s}$ and $72{ }^{\circ} \mathrm{C}$ for $45 \mathrm{~s}$ with a $10 \mathrm{~min}$ final extension step at $72{ }^{\circ} \mathrm{C}$. The PCR products were separated on agarose gel $3 \%$ stained with Midori green.

\section{Polymorphism of the voltage-gated sodium channel (VGSC) gene}

To assess the polymorphism of the VGSC gene and detect possible signatures of selection, a fragment of this gene spanning the F1534C mutation (a part of segment 6 of Domain III) was amplified and sequenced in $130 G_{0}$ field collected mosquitoes from 13 locations across Cameroon. PCR reactions were carried out using $10 \mathrm{pmol}$ of each primer [aegSCF7 (GAGAACTCGCCGATGAAC TT) and aegSCR7 (GACGACGAAATCGAACAGGT)] and $20 \mathrm{ng}$ of genomic DNA as template in $15 \mu \mathrm{l}$ reactions containing $1 \times$ Kapa Taq buffer, $0.2 \mathrm{mmol} / \mathrm{L}$ dNTPs, $1.5 \mathrm{mmol} / \mathrm{L} \mathrm{MgCl}_{2}$, 1U Kapa Taq (Kapa biosystems) [38]. The cycle conditions were $94{ }^{\circ} \mathrm{C}$ for $3 \mathrm{~min}, 35$ cycles of $94{ }^{\circ} \mathrm{C}$ for $15 \mathrm{~s}, 55^{\circ} \mathrm{C}$ for $30 \mathrm{~s}$, and $72{ }^{\circ} \mathrm{C}$ for $30 \mathrm{~s}$, followed by a final elongation step at $72{ }^{\circ} \mathrm{C}$ for $10 \mathrm{~min}$. Amplicons from the PCR were analysed by agarose gel electrophoresis stained with Midori green and visualized under UV light. The amplified fragments of the expected size were purified using ExoSAP following manufacturer recommendations and directly sent for sequencing. The sequences were corrected with BioEdit software (v 7.1.8, London information retrieval ltd, London, UK) and aligned with Clustal W [39]. DNAsp (v 6.10.01, Universitat de Barcelona, Barcelona, Spain) [40] was used to define the haplotype phase and compute the genetic parameters including the number of haplotypes (h), the number of polymorphism sites $(S)$, haplotype diversity (Hd), and nucleotide diversity $(\pi)$. The statistical tests of Tajima [41] and Fu Fs [42] were estimated with DnaSP in order to establish non-neutral evolution and deviation from mutation-drift equilibrium. Different haplotypes obtained and reference sequences were used to construct the maximum likelihood phylogenetic tree using Mega 6.0 [43]. A haplotype network was built using TCS [44] and TcsBu [45] programs to further assess the genealogical relationship between haplotypes.

\section{Results \\ Larval bioassays}

Larval assays were tested with temephos for three populations due to the limited number of larvae (Table 1). Analysis revealed that the resistance ratio for all populations tested was less than 2 suggesting the susceptibility of these populations to temephos.

\section{Insecticide resistance profile in adults}

Bioassays were performed in $10 \mathrm{Ae}$. aegypti populations collected across Cameroon (Figs. 2 and 3). Analysis revealed that four populations out of 10 were resistant to DDT with mortality rate ranging from $16.8 \%$ in Douala to $77.3 \%$ in Ngaoundéré populations. Six other populations 
Table 1 Larval bioassays with temephos against Aedes aegypti larvae

\begin{tabular}{|c|c|c|c|c|c|}
\hline Strain and Site & $n$ & $\mathrm{LC}_{95}(\mathrm{mg} / \mathrm{L})(95 \% \mathrm{Cl})$ & $\mathrm{RR}_{\mathbf{9 5}}$ & $\mathrm{LC}_{50}(\mathrm{mg} / \mathrm{L})(95 \% \mathrm{Cl})$ & $\mathrm{RR}_{50}$ \\
\hline NO lab strain & 531 & $\begin{array}{l}0.0046 \\
(0.0042-0.0051)\end{array}$ & - & $\begin{array}{l}0.0026 \\
(0.0025-0.0028)\end{array}$ & - \\
\hline Edéa & 531 & $\begin{array}{l}0.0046 \\
(0.0036-0.0094)\end{array}$ & 1.00 & $\begin{array}{l}0.0021 \\
(0.0007-0.0028)\end{array}$ & 0.80 \\
\hline Douala & 483 & $\begin{array}{l}0.0078 \\
(0.0069-0.0092)\end{array}$ & 1.68 & $\begin{array}{l}0.0039 \\
(0.0037-0.0042)\end{array}$ & 1.47 \\
\hline Yaoundé & 537 & $\begin{array}{l}0.0034 \\
(0.00258-0.0069)\end{array}$ & 0.74 & $\begin{array}{l}0.0015 \\
(0.0009-0.0020)\end{array}$ & 0.59 \\
\hline
\end{tabular}

$n$ number of larvae tested; $\mathrm{LC}_{95}$ and $\mathrm{LC}_{50} 95$ and 50\% lethal concentrations; $\mathrm{Cl}$ Confidence interval; RR resistance ratio; NO New Orleans

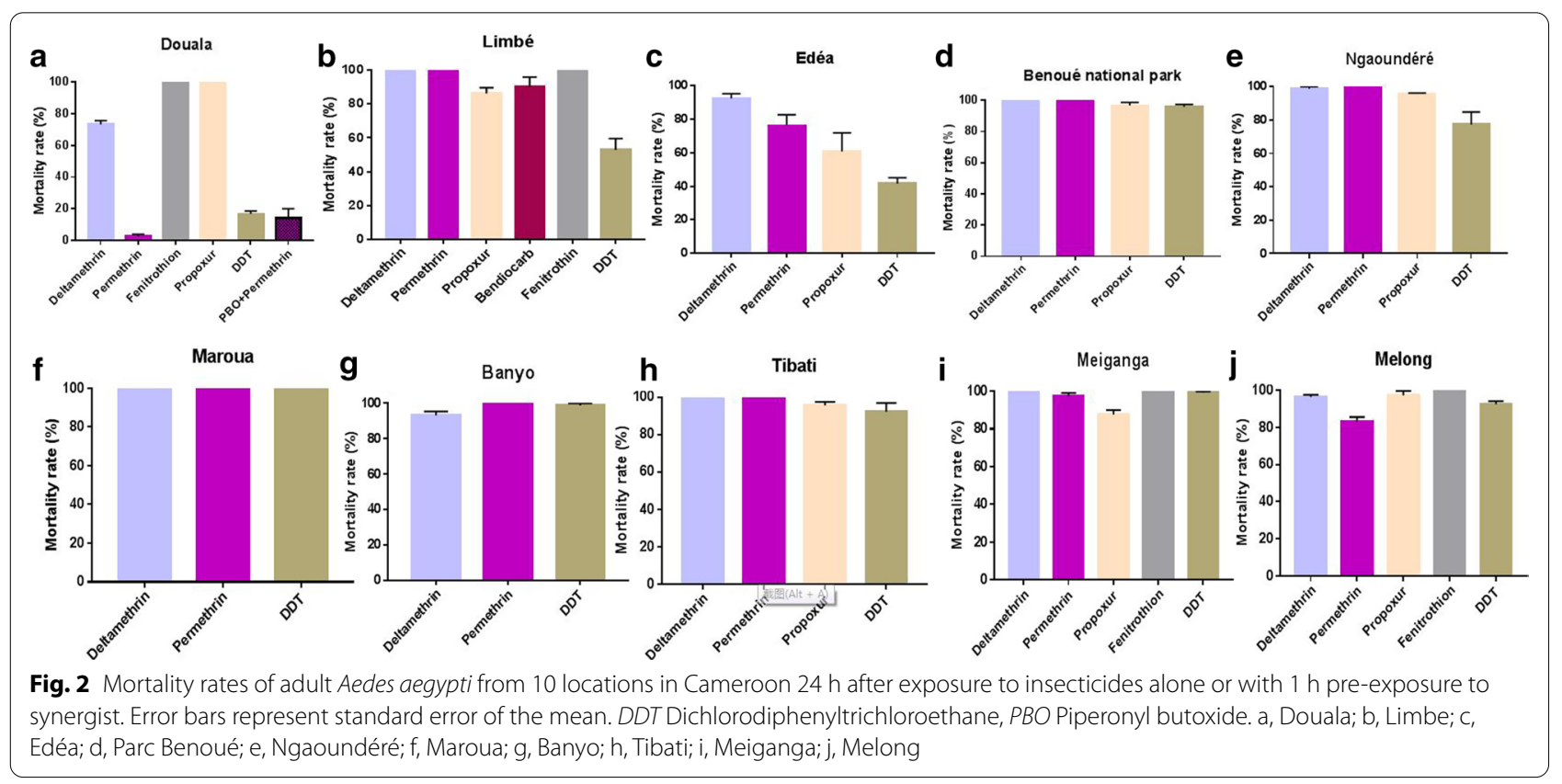

were either probable resistant or susceptible with percentage of mortality varying from $92.32 \%$ in Tibati to $100 \%$ in Maroua. A good susceptibility level was observed against both pyrethroids tested, type I pyrethroid permethrin and type II pyrethroid deltamethrin, with six susceptible populations, two probable resistant and two resistant populations with lowest mortality rate (2.56\%) in Douala population for permethrin (Fig. 2). A moderate level of resistance was reported against carbamates notably to propoxur for which mortality rates between of $60.82 \%$ and $87.71 \%$ in Edéa and in Meiganga populations, respectively. Nevertheless, probable resistance was detected in four populations with mortality rate ranging from $95.65 \%$ in Tibati to $97.33 \%$ in Melong. Only one population (Douala) was fully susceptible to propoxur. The unique population from Limbé tested to bendiocarb was resistant with mortality rate of $82.95 \%$. All populations tested across Cameroon exhibited a full susceptibility toward the organophosphate fenitrothion which is in line with temephos susceptibility observed in larvae (Fig. 3).

\section{Synergist assay with PBO}

The synergist assay analysis revealed a partial recovery of susceptibility to permethrin after $\mathrm{PBO}$ pre-exposure (Fig. 2) to Douala population $(2.56 \pm 1.48 \%$ without PBO vs $14.28 \pm 5.8 \%$ with $\mathrm{PBO}, P<0.005)$ suggesting that the cytochrome $\mathrm{P} 450$ monooxygenases are also playing a role in pyrethroids resistance in this populaton.

\section{F1534C $k d r$ genotyping using allele specific PCR}

A total of 331 specimens of Ae. aegypti from 13 locations across Cameroon was successfully amplified (Table 2). Among them, 320 (96.68\%) were susceptible (1534 F/F), $8(2.41 \%)$ were heterozygote resistant $(1534 \mathrm{~F} / \mathrm{C})$, and 3 (0.91\%) were homozygote resistant $(1534 \mathrm{C} / \mathrm{C})$. Overall, allelic frequency of susceptible was 0.98 while for resistant was 0.02 . The F1534C mutation was found in only 


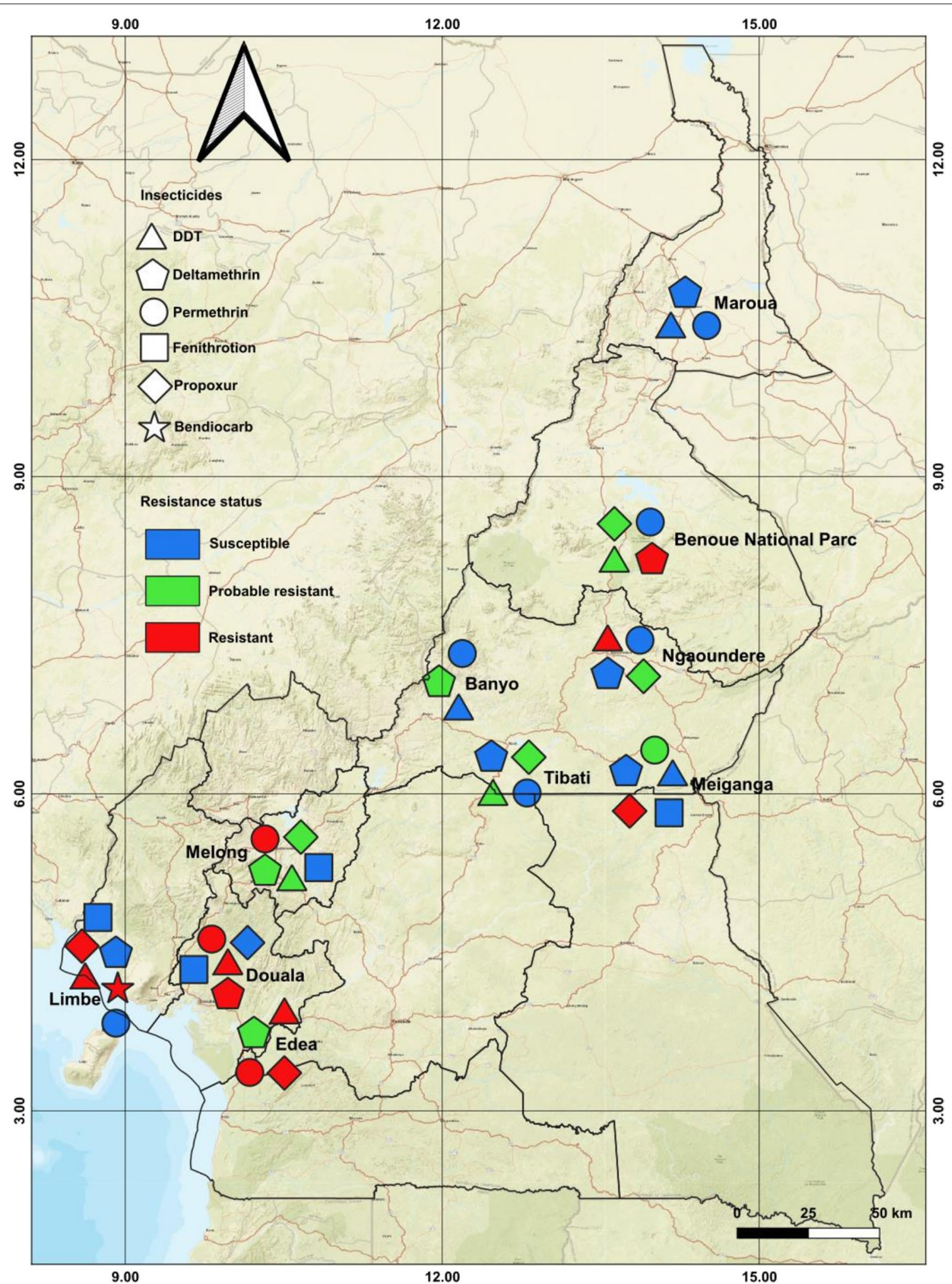

Fig. 3 Map showing the insecticide resistance status of Aedes aegypti in Cameroon. DDT: Dichlorodiphenyltrichloroethane 
Table 2 F1534C genotype numbers and the allelic frequency of the C mutation of Aedes aegypti

\begin{tabular}{|c|c|c|c|c|c|c|}
\hline \multirow[t]{2}{*}{ Location } & \multicolumn{3}{|c|}{ F1534 genotypes } & \multirow[t]{2}{*}{$\mathrm{FF}+\mathrm{FC}+\mathrm{CC}$} & \multicolumn{2}{|c|}{ Allelic frequencies } \\
\hline & $\mathrm{FF}$ & $\mathrm{FC}$ & $\mathrm{CC}$ & & $\% \mathrm{~F}$ & $\% \mathrm{C}$ \\
\hline Benoué national park & 24 & 0 & 0 & 24 & 100 & 0 \\
\hline Maroua & 27 & 0 & 0 & 27 & 100 & 0 \\
\hline Garoua & 30 & 0 & 0 & 30 & 100 & 0 \\
\hline Mbé & 17 & 0 & 0 & 17 & 100 & 0 \\
\hline Ngaoundéré & 25 & 0 & 0 & 25 & 100 & 0 \\
\hline Banyo & 29 & 0 & 0 & 29 & 100 & 0 \\
\hline Tibati & 26 & 0 & 0 & 26 & 100 & 0 \\
\hline Meiganga & 24 & 0 & 0 & 24 & 100 & 0 \\
\hline Edéa & 29 & 0 & 1 & 30 & 96.67 & 3.33 \\
\hline Limbé & 27 & 0 & 0 & 27 & 100 & 0 \\
\hline Douala & 8 & 8 & 2 & 18 & 66.67 & 33.33 \\
\hline Melong & 24 & 0 & 0 & 24 & 100 & 0 \\
\hline Yaoundé & 30 & 0 & 0 & 30 & 100 & 0 \\
\hline Total & 320 & 8 & 3 & 331 & 97.89 & 2.11 \\
\hline
\end{tabular}

F: phenylalanine; C: cysteine; F/F: absence of the F1534C mutation; F/C: presence of the F1534C mutation with 2 alleles: one resistant, allele C and another susceptible $\mathrm{F}$ allele; $\mathrm{C} / \mathrm{C}$ : presence of the $\mathrm{F} 1534 \mathrm{C}$ mutation with the 2 resistant alleles

two populations: Edéa and Douala with allelic frequencies of $3.33 \%$ and $33.33 \%$ respectively (Table 2 ).

\section{Genetic diversity of VGSC in Ae. aegypti}

One hundred and twenty-two field collected Ae. aegypti from 13 locations were successfully sequenced for a 201 bp fragment of the VGSC gene spanning the codon 1534. Analysis confirmed the presence of mutation 1534C in Douala and Edéa samples (Fig. 4). Overall, 25 polymorphic sites, 38 haplotypes (46 haplotypes, when taking into account insertions or deletions) with a high haplotype diversity (0.879) and low nucleotide diversity (0.010) (Table 3). Among these haplotypes,
H1 (15.98\%), H10 (13.93\%), H2 (9.83\%) and H3 (9.42\%) were the most represented (Fig. 5a). The resistant haplotype H36 was detected in Douala (80\%) and Edéa (20\%) populations (Fig. 5a, b). A maximum likelihood (ML) tree of the sequences analysed confirms a high diversity with the probable four clusters (Fig. 5c). Globally, all the statistics estimated were negatives $(\mathrm{D}=-1.479$, Fu's Fs $=-33.498)$ with Fu's Fs statistically significant (Table 3). Negative values for these indexes indicate an excess of rare polymorphisms in a population and suggest a recent expansion of the gene studied across the populations or background selection.

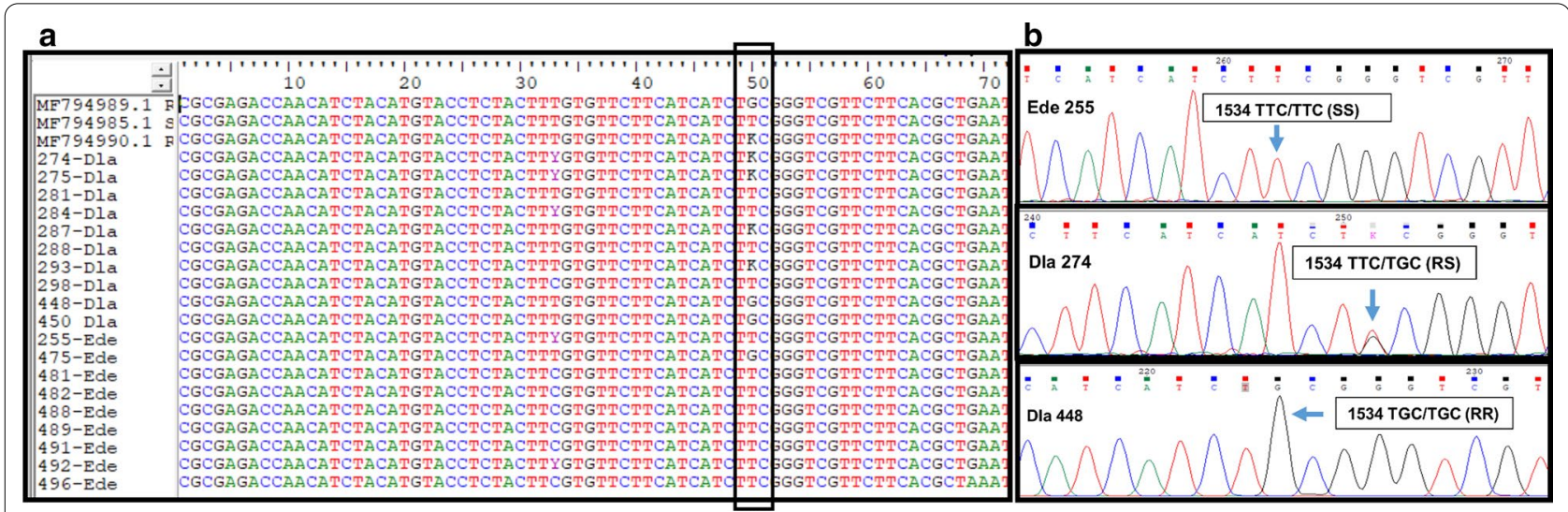

Fig. 4 3: Sequencing of the portion of the voltage gated sodium channel gene spanning the F1534C mutation. a Sequence alignment of the voltage gated sodium channel gene at the F1534C point mutation in field collected adult mosquitoes (F0), b Chromatogram traces showing the three genotypes at the 1534 coding position 
Table 3 Genetic diversity parameters of F1534C mutation among Cameroonian Aedes aegypti populations

\begin{tabular}{llllllllll}
\hline Populations & $\mathbf{2 N}$ & $\mathbf{S}$ & Syn & Nsyn & $\mathbf{\pi}$ & H & Hd & D & Fu Fs \\
\hline Benoué national park & 20 & 5 & 4 & 1 & 0.006 & 6 & 0.726 & -0.591 & -1.874 \\
Maroua & 18 & 5 & 4 & 1 & 0.006 & 5 & 0.745 & -0.703 & -0.945 \\
Garoua & 20 & 9 & 7 & 2 & 0.011 & 9 & 0.863 & -0.592 & $-3.113^{*}$ \\
Mbe & 18 & 9 & 8 & 1 & 0.014 & 9 & 0.922 & 0.023 & $-2.581^{*}$ \\
Ngaoundéré & 20 & 6 & 6 & 0 & 0.007 & 6 & 0.763 & -0.479 & -1.195 \\
Banyo & 16 & 7 & 5 & 2 & 0.012 & 9 & 0.908 & 0.318 & $-3.584^{*}$ \\
Tibati & 20 & 5 & 4 & 1 & 0.008 & 8 & 0.868 & 0.379 & $-3.062^{*}$ \\
Meiganga & 20 & 12 & 11 & 1 & 0.013 & 9 & 0.847 & -1.020 & $-2.544^{*}$ \\
Douala & 20 & 6 & 4 & 2 & 0.008 & 7 & 0.784 & -0.122 & -1.850 \\
Limbé & 20 & 5 & 4 & 1 & 0.009 & 8 & 0.853 & 0.836 & $-2.590^{*}$ \\
Melong & 14 & 7 & 7 & 0 & 0.011 & 6 & 0.813 & -0.097 & -0.787 \\
Yaoundé & 20 & 5 & 4 & 1 & 0.006 & 7 & 0.800 & -0.283 & $-2.653^{*}$ \\
Edéa & 18 & 8 & 6 & 2 & 0.009 & 9 & 0.895 & -0.740 & $-4.088^{*}$ \\
Total & 244 & 25 & 18 & 8 & 0.010 & 38 & 0.879 & -1.479 & $33.498^{* * *}$ \\
\hline
\end{tabular}

$2 \mathrm{~N}$, number of sequences; $\mathrm{S}$, number of polymorphic sites; $\mathrm{h}$, number of haplotypes; $\mathrm{Hd}$, haplotype diversity; $\pi$, nucleotide diversity; Syn and Nsyn, synonymous and non-synonymous mutation; D and Fs, Tajima's D and Fu Fs statistics, ${ }^{*}$ degree of significance

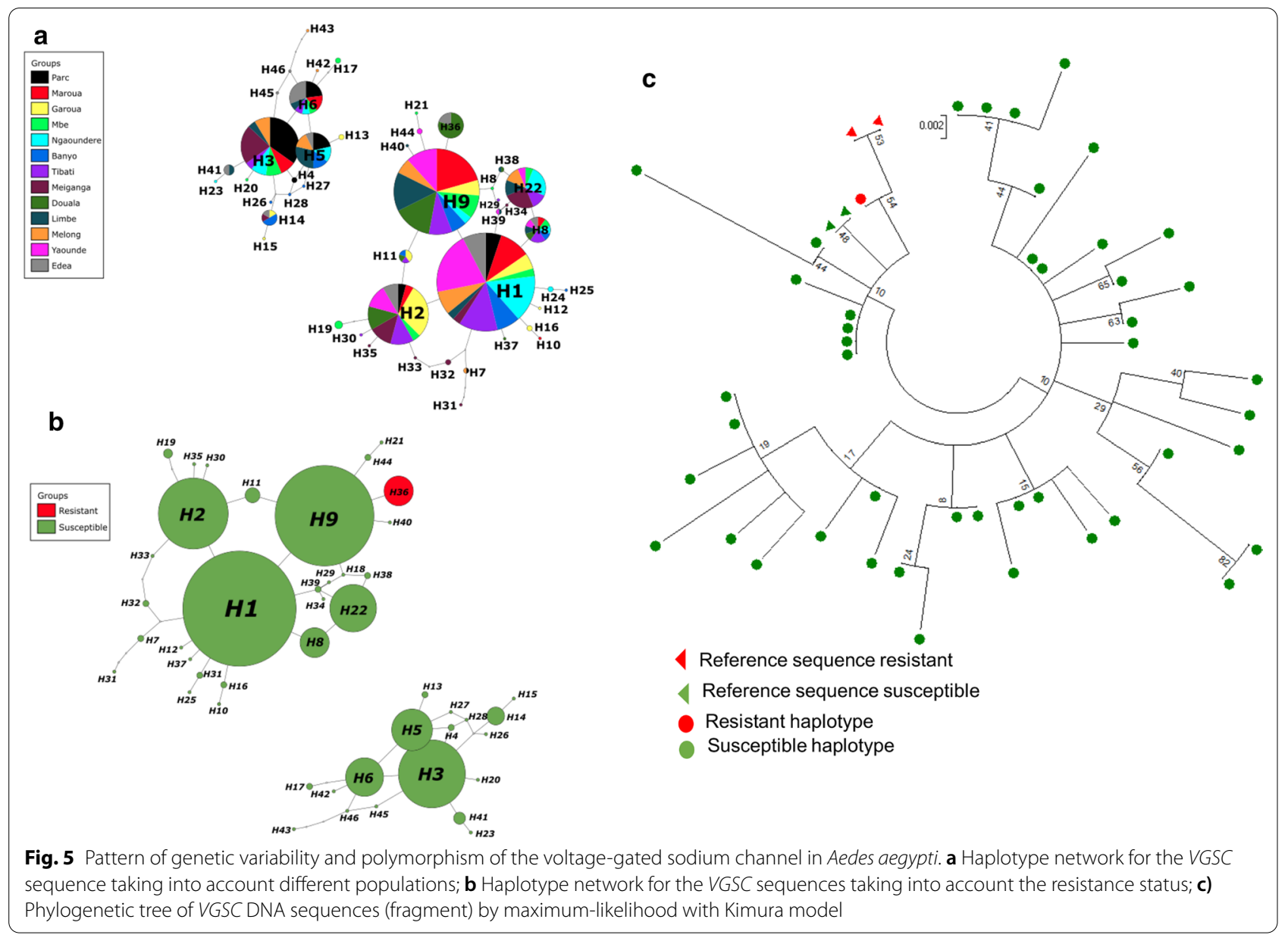




\section{Discussion}

This study investigated the nationwide insecticide profile of Ae. aegypti in Cameroon and assessed the contribution of F1534C $k d r$ mutation in insecticide resistance. Larval bioassays analysis revealed that all Ae. aegypti populations tested were susceptible to the organophosphate temephos. This observation is similar to those made by previous studies from several countries in Central Africa such as in Cameroon [19], Central African Republic [18], and Republic of the Congo [24]. Nonetheless, the resistance of Ae. aegypti to this compound was reported in several countries such as in Laos [23], Brazil [46], Thailand [47], Malaysia [48], and Cape Verde [49]. This organophosphate is the larvicide mainly used to control Aedes larvae by treating water storage containers [46, $50,51]$. However, selection of the resistance results from extensive and long-term use of the product incriminated, whereas in our knowledge, temephos had never been used in vector control programs in Cameroon. This probably explains the full susceptibility reported in Ae. aegypti as suggested previously [19].

Adult bioassays analysis revealed that four Ae. aegypti samples were found resistant to DDT and the remaining were either susceptible or probably resistant. A decreasing susceptibility of the Ae. aegypti population from Yaoundé and Brazzaville towards DDT was already mentioned in 1970s [52], suggesting that this resistance may have resulted from a continuing selection pressure on Aedes populations as suggested previously [18, 19]. Indeed, recent study in Central Africa reported the resistance of $A$ e. aegypti to DDT [18, 20, 24]. The full susceptibility reported in some populations such as in Maroua and Meiganga shows that the DDT resistance is not nationwide in Cameroon and suggests that this compound can still be effective to control Ae. aegypti.

Aedes aegypti populations showed a good level of susceptibility toward type I pyrethroid permethrin with only three resistant populations out of 10 tested. The loss of susceptibility to this pyrethroid was previously reported in Cameroon [20] and outside Africa [23, 48]. Similarly, a good level susceptibility was reported against type II pyrethroid deltamethrin. These results suggest that the resistance to deltamethrin and permethrin has not yet spread country-wide and these insecticides are still effective to control Aedes in some locations of Cameroon. A loss of sensitivity was observed to carbamates notably propoxur with moderate level of resistance in some locations such as: Limbé, Edéa, and Tibati. This result is comparable to previous reports in the Republic of the Congo [24] and in Burkina Faso [29] in Africa and in several countries outside Africa such as Malaysia [48], Pakistan [53], and Saudi Arabia [54]. The source of selection driving the observed resistance to DDT, permethrin, deltamethrin, propoxur and bendiocarb in some $A e$. aegypti populations remains unclear notably as the use of insecticides against Aedes is limited in the region [19, 20]. As suggested previously $[18,20]$, domestic used of insecticides through the indoor spraying and impregnating bed nets, and agriculture use could be the main source of resistance selection in Aedes vectors in Central Africa. Indeed, the use of pesticides in agriculture for the protection of market gardening could also promoted the emergence of resistance in mosquitoes by contamination of breeding sites and resting places of mosquitoes [55].

A partial recovery of susceptibility to permethrin was reported in Douala population after pre-exposure to $\mathrm{PBO}$ synergist. This result indicates that the cytochrome $\mathrm{P} 450$ monooxygenases are playing a role in the observed resistance perhaps in association with other enzyme families or/and other resistance mechanisms as the recovery was only modest. The implication of cytochrome P450 monooxygenases in Ae. aegypti resistance has been previously reported in several regions in the world including Central Africa the sub-region $[18,20]$.

The F1534C mutation is common in Ae. aegypti and has a worldwide distribution [22] although it was not yet detected in Cameroon [20]. Our analysis revealed the first evidence of this mutation in Ae. aegypti from two locations (Edéa and Douala) of Cameroon. This $k d r$ mutation was previously reported in Africa in Ghana [21] and Burkina Faso [29, 35]. The allelic frequency of this mutation observed in Cameroon (3.3-33.3\%) is low compared to those found in Ghana for example (33.3$68.42 \%$ ) [21]. In fact, the result of neutrality test suggests a recent selection of this mutation in Cameroon with a potential origin from Douala. The presence of a unique resistant haplotype H36 support a unique origin of the 1534C allele in Cameroon probably in Douala with a gradual spread in the country. As Douala is the main port of Cameroon, it is not excluded that the $1534 \mathrm{C}$ may have been imported recently instead of a de novo local selection. Indeed, our sequences clustered with the reference sequences downloaded in GenBank (accession numbers: MF794989.1, MF794985.1 and MF794990.1) coming from Thailand [56].

The absence of a reduced diversity at the VGSC in Douala and Edéa as shown from ML tree and TCS haplotype network is due to recent selection of this resistant allele in these locations which is further supported by the low frequency of homozygote CC. However, these populations will need to be monitored as increasing pressure may lead to the further selection associated with reduced diversity as seen in other locations such as in Malaysia [48] for Ae. aegypti. Such increasing selection pressure on mosquitoes populations have also been observed for metabolic resistance genes such as GSTe2 for the L119F 
in Benin [57] or cytochrome P450 (CYP6P9a/b) [58-60] leading to drastic reduced diversity.

In addition, it will be interesting to genotype other mutations such as 1016 and 410 which have been found implicated in $k d r$ resistance in Ae. aegypti [22, 28-30] and investigate the genes involved in metabolic resistance such as CYP9 overexpressed in several regions worldwide including in Africa [35].

\section{Conclusions}

Our result revealed a variable level of susceptibility among populations towards insecticides tested across the country. The full susceptibility to organophosphates at both larval (temephos) and adult stages (fenitrothion) makes this insecticide class very suitable for control $A e$. aegypti in Cameroon. Furthermore, this study revealed for the first time the presence of target site mutation F1534C in Cameroon. Data generated in this study could serve as baseline to implement further investigations and planning efficient insecticide-based interventions against Ae. aegypti in Cameroon.

\section{Abbreviations \\ AS: Allele specific; DDT: Dichlorodiphenyltrichloroethane; DNA: Deoxyribonu- cleic acid; kdr: Knockdown resistance; LC: Lethal concentration; PBO: Piperonyl butoxide; PCR: Polymerase chain reaction; RR: Resistance ratio; VCRU: Vector control research unit; VGSC: Voltage-gated sodium channel; WHO: World Health Organization.}

\section{Acknowledgements}

We thank the people living around all the different collection sites and the garage owners for their cooperation during the field investigations.

\section{Authors' contributions}

APY, BK, FN and CSW conceived and designed the experiments. APY, BK, and ANT participated in mosquito collections. APY and TAWB performed the bioassays. APY, TAWB, DNN and BK carried out the data analyses. APY conducted the molecular analyses. APY, BK and CSW wrote the paper. All authors read and approved final version of the manuscript.

\section{Funding}

This study was supported by the Wellcome Trust Training Fellowship in Public Health and Tropical Medicine (204862/Z/16/Z) awarded to BK. The funders had no role in study design, data collection or analysis, decision to publish or preparation of the manuscript.

\section{Availability of data and materials}

All the relevant data generated during this study are included in the manuscript.

\section{Ethics approval and consent to participate}

An ethical clearance No. 2017/05/911/CE/CNERSH/SP was delivered by the Cameroonian National Ethics Committee for Human Health Research for this study. An oral consent form was obtained from the head or representative of each household owner prior to the survey.

\section{Consent for publication}

Not applicable.

\section{Competing interests}

The authors declare that they have no competing interests.

\section{Author details}

${ }^{1}$ Centre for Research in Infectious Diseases, P.O. Box 13591, Yaoundé, Cameroon. ${ }^{2}$ Parasitology and Ecology Laboratory, Department of Animal Biology and Physiology, Faculty of Science, University of Yaoundé 1, P.O. Box 812, Yaoundé, Cameroon. ${ }^{3}$ Laboratory of Vertebrate and Invertebrate Bioecology, Faculty of Science and Technology, Marien-Ngouabi University, Brazzaville, Congo. ${ }^{4}$ Laboratory of Biology and Applied Ecology, Department of Animal Biology, Faculty of Science, University of Dschang, P.O. Box 96, Dschang, Cameroon. ${ }^{5}$ Liverpool School of Tropical Medicine, Pembroke place, Liverpool L3 $5 \mathrm{QA}, \mathrm{UK}$.

Received: 25 June 2020 Accepted: 19 October 2020

Published online: 02 November 2020

\section{References}

1. Morrison AC, Zielinski-Gutierrez E, Scott TW, Rosenberg R. Defining challenges and proposing solutions for control of the virus vector Aedes aegypti. PLoS Med. 2008;5(3):e68.

2. Simo FBN, Yousseu FBS, Mbarga AE, Bigna JJ, Melong A, Ntoude A, Kamgang B, Bouyne R, Fewou PM, Demanou M. Investigation of an outbreak of dengue virus serotype 1 in a rural area of Kribi, South Cameroon: a cross-sectional study. Intervirology. 2018;61(6):265-71.

3. Tchuandom SB, Tchadji JC, Tchouangueu TF, Biloa MZ, Atabonkeng EP, Fumba MIM, Massom ES, Nchinda G, Kuiate J-R. A cross-sectional study of acute dengue infection in paediatric clinics in Cameroon. BMC Public Health. 2019;19(1):958.

4. Monamele GC, Demanou M. First documented evidence of dengue and malaria co-infection in children attending two health centers in Yaounde, Cameroon. PAMJ. 2018;29:227.

5. Yousseu FBS, Nemg FBS, Ngouanet SA, Mekanda FMO, Demanou M. Detection and serotyping of dengue viruses in febrile patients consulting at the New-Bell District Hospital in Douala, Cameroon. PLoS ONE. 2018;13(10):e0204143.

6. Peyrefitte CN, Rousset D, Pastorino BA, Pouillot R, Bessaud M, Tock F, Mansaray H, Merle OL, Pascual AM, Paupy C. Chikungunya virus, Cameroon, 2006. Emerg Infect Dis. 2007;13(5):768.

7. Demanou M, Antonio-Nkondjio C, Ngapana E, Rousset D, Paupy C, Manuguerra J-C, Zeller $\mathrm{H}$. Chikungunya outbreak in a rural area of Western Cameroon in 2006: a retrospective serological and entomological survey. BMC Res Notes. 2010:3(1):128

8. Noah BDN, Pouth FBB, Ndode C, Bohimbo C, Evouna A, Kouamen G, Els M. Yellow fever (YF) remains a public health problem in Cameroon: descriptive analysis of the national database (2010-2016, 50th epidemiological week). PAMJ. 2017;3(3):52.

9. Gake B, Vernet MA, Leparc-Goffart I, Drexler JF, Gould EA, Gallian P. Lamballerie Xd: low seroprevalence of Zika virus in Cameroonian blood donors. Braz J Infect Dis. 2017:21(4):481-3.

10. Tedjou AN, Kamgang B, Yougang AP, Njiokou F, Wondji CS. Update on the geographical distribution and prevalence of Aedes aegypti and Aedes albopictus (Diptera: Culicidae), two major arbovirus vectors in Cameroon. PLoS Negl Trop Dis. 2019;13(3):e0007137.

11. Kamgang $B$, Vazeille $M$, Tedjou AN, Wilson-Bahun TA, Yougang AP, Mousson L, Wondji C, Failloux A-B. Risk of dengue in Central Africa: vector competence studies with Aedes aegypti and Aedes albopictus (Diptera: Culicidae) populations and dengue 2 virus. PLoS Negl Trop Dis. 2019;13(12):e0007985.

12. Kamgang B, Vazeille M, Tedjou A, Yougang AP, Wilson-Bahun TA, Mousson L, Wondji CS, Failloux A-B. Different populations of Aedes aegypti and Aedes albopictus (Diptera: Culicidae) from Central Africa are susceptible to Zika virus infection. PLoS Negl Trop Dis. 2020;14(3):e0008163.

13. Kamgang B, Vazeille M, Yougang AP, Tedjou AN, Wilson-Bahun TA, Mousson L, Wondji CS, Failloux A-B. Potential of Aedes albopictus and Aedes aegypti (Diptera: Culicidae) to transmit yellow fever virus in urban areas in Central Africa. Emerg Microbes Infect. 2019;8(1):1636-41.

14. Lenhart A, Orelus N, Maskill R, Alexander N, Streit T, McCall P. Insecticidetreated bednets to control dengue vectors: preliminary evidence from a controlled trial in Haiti. Trop Med Int Health. 2008;13(1):56-67. 
15. WHO: Vector control operations framework for Zika virus. Geneva: WHO, WHO/ZIKV/NC/164. 2016:10.

16. Kroeger A, Lenhart A, Ochoa M, Villegas E, Levy M, Alexander N, McCall PJ. Effective control of dengue vectors with curtains and water container covers treated with insecticide in Mexico and Venezuela: cluster randomised trials. BMJ. 2006;332(7552):1247-52.

17. Polson KA, Rawlins SC, Brogdon WG, Chadee DD. Characterisation of DDT and pyrethroid resistance in Trinidad and Tobago populations of Aedes aegypti. Bull Entomol Res. 2011;101(4):435-41.

18. Ngoagouni C, Kamgang B, Brengues C, Yahouedo G, Paupy C, Nakoune E, Kazanji M, Chandre F. Susceptibility profile and metabolic mechanisms involved in Aedes aegypti and Aedes albopictus resistant to DDT and deltamethrin in the Central African Republic. Parasit Vectors. 2016;9(1):599.

19. Kamgang B, Marcombe S, Chandre F, Nchoutpouen E, Nwane P, Etang J, Corbel V, Paupy C. Insecticide susceptibility of Aedes aegypti and Aedes albopictus in Central Africa. Parasit Vectors. 2011:4:79.

20. Kamgang B, Yougang AP, Tchoupo M, Riveron JM, Wondji C. Temporal distribution and insecticide resistance profile of two major arbovirus vectors Aedes aegypti and Aedes albopictus in Yaoundé, the capital city of Cameroon. Parasites Vectors. 2017;10(1):469.

21. Kawada H, Higa Y, Futami K, Muranami Y, Kawashima E, Osei JH, Sakyi KY, Dadzie S, de Souza DK, Appawu M. Discovery of point mutations in the voltage-gated sodium channel from African Aedes aegypti populations: potential phylogenetic reasons for gene introgression. PLoS Negl Trop Dis. 2016;10(6):e0004780.

22. Moyes CL, Vontas J, Martins AJ, Ng LC, Koou SY, Dusfour I, Raghavendra K, Pinto J, Corbel V, David J-P. Contemporary status of insecticide resistance in the major Aedes vectors of arboviruses infecting humans. PLOS Negl Trop Dis. 2017;11(7):e0005625.

23. Marcombe S, Fustec B, Cattel J, Chonephetsarath S, Thammavong P, Phommavanh N, David J-P, Corbel V, Sutherland IW, Hertz JC. Distribution of insecticide resistance and mechanisms involved in the arbovirus vector Aedes aegypti in Laos and implication for vector control. PLoS Negl Trop Dis. 2019;13(12):e0007852.

24. Kamgang B, Wilson-Bahun TA, Yougang AP, Lenga A, Wondji CS. Contrasting resistance patterns to type I and II pyrethroids in two major arbovirus vectors Aedes aegypti and Aedes albopictus in the Republic of the Congo, Central Africa. Infect Dis Poverty. 2020;9(1):1-10.

25. David J-P, Ismail HM, Chandor-Proust A, Paine MJI. Role of cytochrome P450s in insecticide resistance: impact on the control of mosquito-borne diseases and use of insecticides on Earth. Philos Trans R Soc Lond Ser B Biol Sci. 2013:368(1612):20120429.

26. Hemingway J, Hawkes NJ, McCarroll L, Ranson H. The molecular basis of insecticide resistance in mosquitoes. Insect Biochem Mol Biol. 2004;34(7):653-65.

27. Perry T, Batterham P, Daborn PJ. The biology of insecticidal activity and resistance. Insect Biochem Mol Biol. 2011:41(7):411-22.

28. Haddi K, Tomé HV, Du Y, Valbon WR, Nomura Y, Martins GF, Dong K, Oliveira EE. Detection of a new pyrethroid resistance mutation (V410L) in the sodium channel of Aedes aegypti: a potential challenge for mosquito control. Sci Rep. 2017;7:46549.

29. Sombié A, Saiki E, Yaméogo F, Sakurai T, Shirozu T, Fukumoto S, Sanon A, Weetman D, McCall PJ, Kanuka H. High frequencies of F1534C and V1016l kdr mutations and association with pyrethroid resistance in Aedes aegypti from Somgandé (Ouagadougou), Burkina Faso. Trop Med Health. 2019;47(1):2.

30. Ayres CF, Seixas G, Borrego S, Marques C, Monteiro I, Marques CS, Gouveia B, Leal S, Troco AD, Fortes F. The V410L knockdown resistance mutation occurs in island and continental populations of Aedes aegypti in West and Central Africa. PLoS Negl Trop Dis. 2020;14(5):e0008216.

31. Jupp PG. Mosquitoes of southern Africa: Culicinae and Toxorhynchitinae. Johannesburg: Ekogilde Publishers; 1996.

32. Edwards FW. Mosquitoes of the Ethiopian Region III-Culicine adults and pupae. London: British Museum (Natural History); 1941

33. WHO. Entomological surveillance for Aedes spp. in the context of Zika virus interim guidance for entomologists. Geneva: WHO; 2016.

34. WHO: Monitoring and managing insecticide resistance in Aedes mosquito populations. Geneva: WHO, WHO/ZIKV/VC/161. 2016.

35. Badolo A, Sombié A, Pignatelli PM, Sanon A, Yaméogo F, Wangrawa DW, Sanon A, Kanuka H, McCall PJ, Weetman D. Insecticide resistance levels and mechanisms in Aedes aegypti populations in and around Ouagadougou, Burkina Faso. PLoS Negl Trop Dis. 2019;13(5):e0007439.

36. Livak KJ. Organization and mapping of a sequence on the Drosophila melanogaster $X$ and $Y$ chromosomes that is transcribed during spermatogenesis. Genetics. 1984;107(4):611-34.

37. Harris AF, Rajatileka S, Ranson H. Pyrethroid resistance in Aedes aegypti from Grand Cayman. Am J Trop Med Hyg. 2010;83(2):277-84.

38. Kasai S, Ng LC, Lam-Phua SG, Tang CS, Itokawa K, Komagata O, Kobayashi $\mathrm{M}$, Tomita $\mathrm{T}$. First detection of a putative knockdown resistance gene in major mosquito vector, Aedes albopictus. Jpn J Infect Dis. 2011;64(3):217-21.

39. Hall TA: BioEdit: a user-friendly biological sequence alignment editor and analysis program for Windows 95/98/NT. In: Nucleic acids symposium series: 1999. [London]: Information Retrieval Ltd., c1979-c2000:: 95-98.

40. Rozas J, Ferrer-Mata A, Sánchez-DelBarrio JC, Guirao-Rico S, Librado P, Ramos-Onsins SE, Sánchez-Gracia A. DnaSP 6: DNA sequence polymorphism analysis of large data sets. Mol Biol Evo. 2017;34(12):3299-302.

41. Tajima F. Statistical method for testing the neutral mutation hypothesis by DNA polymorphism. Genetics. 1989;123(3):585-95.

42. Fu Y-X. Statistical tests of neutrality of mutations against population growth, hitchhiking and background selection. Genetics. 1997;147(2):915-25.

43. Tamura K, Stecher G, Peterson D, Filipski A, Kumar S. MEGA6: molecular evolutionary genetics analysis version 6.0. Mol Biol Evol. 2013:30(12):2725-9.

44. Clement M, Posada D, Crandall KA. TCS: a computer program to estimate gene genealogies. Mol Ecol. 2000;9(10):1657-9.

45. dos Santos A, Cabezas M, Tavares A, Xavier R, Branco M. tcsBU: a tool to extend TCS network layout and visualization. Bioinformatics. 2016;32:627-8

46. Valle D, Bellinato DF, Viana-Medeiros PF, Lima JBP. Martins Junior AdJ: resistance to temephos and deltamethrin in Aedes aegypti from Brazil between 1985 and 2017. Mem Inst Oswaldo Cruz. 2019;114:e180544.

47. Chaiphongpachara T, Moolrat L. Insecticide resistance of temephos on Aedes aegypti as dengue vector in Samut Songkhram, Thailand. Ann Trop Med Public Health. 2017;10(6):1439.

48. Ishak IH, Jaal Z, Ranson $\mathrm{H}$, Wondji CS. Contrasting patterns of insecticide resistance and knockdown resistance $(\mathrm{kdr})$ in the dengue vectors Aedes aegypti and Aedes albopictus from Malaysia. Parasit Vectors. 2015;8:181.

49. Rocha HDR, Paiva MHS, Silva NM, de Araújo AP, da Moura AJF, Gómez LF, Ayres CFJ, de Melo Santos MAV. Susceptibility profile of Aedes aegypti from Santiago Island, Cabo Verde, to insecticides. Acta Trop. 2015;152:66-73.

50. Marcombe S, Chonephetsarath S, Thammavong P, Brey PT. Alternative insecticides for larval control of the dengue vector Aedes aegypti in Lao PDR: insecticide resistance and semi-field trial study. Parasites Vectors. 2018:11(1):1-8

51. George L, Lenhart A, Toledo J, Lazaro A, Han WW, Velayudhan R, Ranzinger SR, Horstick O. Community-effectiveness of temephos for dengue vector control: a systematic literature review. PLoS Negl Trop Dis. 2015;9(9):e0004006.

52. Mouchet J, Cordellier R, Germain M, Carnevale P, Barathe J, Sannier C Résistance aux insecticides d'Aedes Aegypti L. et Culex pipiens fatigans en Afrique Centrale. Cah ORSTOM SO Ent méd et Parasitol. 1972:4:341-435.

53. Mohsin M, Naz SI, Khan IA, Jabeen A, Bilal H, Ahmad R, Alshamrani Y. IM E: susceptibility status of Aedes aegypti and Aedes albopictus against insecticides at eastern Punjab, Pakistan. Int J Mosq Res. 2016;3(5):41-6.

54. Al Nazawi AM, Aqili J, Alzahrani M, McCall PJ, Weetman D. Combined target site (kdr) mutations play a primary role in highly pyrethroid resistant phenotypes of Aedes aegypti from Saudi Arabia. Parasites Vectors. 2017;10(1):161.

55. Yougang AP, Kamgang B, Tedjou AN, Wilson-Bahun TA, Njiokou F, Wondji CS. Nationwide profiling of insecticide resistance in Aedes albopictus (Diptera: Culicidae) in Cameroon. PLoS ONE. 2020;15(6):e0234572.

56. Saingamsook J, Saeung A, Yanola J, Lumjuan N, Walton C, Somboon P. A multiplex PCR for detection of knockdown resistance mutations, V1016G and F1534C, in pyrethroid-resistant Aedes aegypti. Parasites Vectors. 2017:10(1):465

57. Riveron JM, Yunta C, Ibrahim SS, Djouaka R, Irving H, Menze BD, Ismail HM, Hemingway J, Ranson H, Albert A. A single mutation in the GSTe2 gene allows tracking of metabolically based insecticide resistance in a major malaria vector. Genome Biol. 2014;15(2):1. 
58. Barnes KG, Weedall GD, Ndula M, Irving H, Mzihalowa T, Hemingway J, Wondji CS. Genomic footprints of selective sweeps from metabolic resistance to pyrethroids in African malaria vectors are driven by scale up of insecticide-based vector control. PLoS Genet. 2017;13(2):e1006539.

59. Mugenzi LMJ, Menze BD, Tchouakui M, Wondji MJ, Irving H, Tchoupo M, Hearn J, Weedall GD, Riveron JM, Wondji CS. Cis-regulatory CYP6P9b P450 variants associated with loss of insecticide-treated bed net efficacy against Anopheles funestus. Nat Commun. 2019;10(1):4652.
60. Weedall GD, Mugenzi LMJ, Menze BD, Tchouakui M, Ibrahim SS, Amvongo-Adjia N, Irving H, Wondji MJ, Tchoupo M, Djouaka R, et al. A cytochrome P450 allele confers pyrethroid resistance on a major African malaria vector, reducing insecticide-treated bednet efficacy. Sci Transl Med. 2019;11(484):7386.
Ready to submit your research? Choose BMC and benefit from:

- fast, convenient online submission

- thorough peer review by experienced researchers in your field

- rapid publication on acceptance

- support for research data, including large and complex data types

- gold Open Access which fosters wider collaboration and increased citations

- maximum visibility for your research: over 100M website views per year

At BMC, research is always in progress.

Learn more biomedcentral.com/submissions 